\title{
PENGARUH KEPEMILIKAN MANAJERIAL, UKURAN PERUSAHAAN, DAN KEBIJAKAN DIVIDEN TERHADAP KEBIJAKAN HUTANG
}

\author{
Imam Hidayat ${ }^{1 *}$, Susiana Nur Fita Sari ${ }^{2}$ \\ Universitas Muhammadiyah Tangerang \\ 1imam_accounting@yahoo.com, ${ }^{2}$ susiananurfitasari98@gmail.com
}

\begin{abstract}
ABSTRAK
Tujuan dari penelitian ini untuk mengetahui pengaruh Kepemilikan Manajerial, Ukuran Perusahaan, dan Kebijakan Dividen terhadap Kebijakan Hutang pada Perusahaan Manufaktur Sektor Industri Barang Konsumsi Yang Terdaftar Di Bursa Efek Indonesia (BEI). Periode penelitian yang digunakan adalah 5 tahun yaitu periode 2015-2019. Populasi penelitian ini meliputi Perusahaan Manufaktur Sektor Industri Barang Konsumsi yang terdaftar di Bursa Efek Indonesia periode 20152019. Teknik pengambilan sampel menggunakan Teknik purposive sampling. Berdasarkan kriteria yang ditetapkan diperoleh jumlah 9 perusahaan. Jenis data yang digunakan adalah data sekunder yang diperoleh dari situs Bursa Efek Indonesia. Metode analisis yang digunakan adalah analisis regresi data panel. Hasil penelitian menunjukkan bahwa Ukuran Perusahaan berpengaruh positif signifikan, Kepemilikan Manajerial dan Kebijakan Dividen tidak berpengaruh. Kepemilikan Manajerial, Ukuran Perusahaan dan Kebijakan Dividen secara bersama-sama berpengaruh terhadap Kebijakan Hutang.
\end{abstract}

Kata Kunci: Kepemilikan Manajerial, Ukuran Perusahaan, Kebijakan Dividen dan Kebijakan Hutang

\section{PENDAHULUAN}

Dalam menjalankan perusahaan nya, manajer dalam pengambilan keputusan pendanaan harus teliti dan sudah dipikirkan sebelum melakukan tindakan yang diambil. Hal ini karena masing-masing sumber pendanaan mempunyai konsekuensi financial. Masalah keputusan pendanaan akan berkaitan dengan pemilihan sumber dana, baik yang berasal dari dalam (internal) maupun dari luar (external). Pembiayaan sangat penting dalam suatu perusahaan untuk kegiatan operasi, pemasaran, dan membuat kebijakan-kebijakan untuk perusahaan. Seorang manajer memiliki peranan yang penting dalam kegiatan operasi, pemasaran, dan membuat kebijakan-kebijakan untuk perusahaan

Gambaran Fenomena terkait kebijakan hutang antara lain PT Tiga Pilar Sejahtera Food Tbk, dikabarkan mengalami kepailitan dalam menjalankan perusahaan informasi bahwa jumlah tagihan utang yang harus dilunasi oleh perusahaan sebesar Rp 498 miliar pada Oktober 2018. Terjadinya hutang pada PT Tiga Pilar Sejahtera Food Tbk (AISA) yaitu karena terus memburuknya performance kinerja keuangan PT Tiga Pilar Sejahtera Food Tbk

(AISA), disusul penundanaan pembayaran bunga obligasi memicu beberapa investor untuk mengurangi porsi saham AISA.

Kebijakan hutang merupakan keputusan penting yang sangat berpengaruh terhadap kondisi suatuperusahaan. Dan kebijakan hutang akan menentukan nilai perusahaan apabila manajemen suatu perusahaan dapat mengelola hutang dengan baik dan benar serta mampu mempertahankan eksistensi perusahaan itu sendiri.

KAJIAN PUSTAKA DAN
PENGEMBANGAN HIPOTESIS
Teori Keagenan (Agency Theory)
Menurut (Jensen dan Meckling, 1976)
menjelaskan hubungan keagenan merupakan


suatu kontrak dibawah satu atau lebih yang melibatkan agent untuk melaksanakan beberapa pelayanan dengan pendelegasian wewenang kepada agent. Pada teori agensi ini yang dimaksud denga principal adalah pemegang saham dan yang dimaksud dengan agen adalah manajemen yang mengelola perusahaan. Hubungan keagenan merupakan suatu kontrak antara principal dan agen. Dan hubungan keagenan dapat menimbulkan masalah pada saat pihak-pihak bersangkutan mempunyai tujuan berbeda, pemilik modal menghendaki bertambahnya kekayaan dan kemakmuran para pemilik modal, sedangkan manajer juga menginginkan bertambahnya kesejahteraan bagi para manajer. Konflik kepentingan antara pemegang saham dan manajer dapat di minimumkan mekanisme pengawasan dengan cara mensejajarkan kepentingan

kepentingan yang terkait tersebut. Namun dengan munculnya mekanisme pengawasan tersebut akan menimbulkan biaya yang disebut agency cost.

\section{Pecking Order Theory}

Dana merupakan salah satu kebutuhan penting dalam sebuah perusahaan untuk menjalankan aktivitas operasionalnya. Sumber dana perusahaan diperoleh melalui dana internal yaitu laba ditahan atau dana eksternal yaitu hutang. Pecking order theory merupakan suatu urutan keputusan pendanaan dimana diambil oleh pihak manajemen dengan urutan pertama laba ditahan, hutang dan yang terakhir penerbitan saham. Perusahaan membutuhkan dana eksternal, maka perusahaan akan lebih memilih external quity. Hutang diperoleh dari pinjaman kreditur, sedangkan external quity diperoleh karena perusahaan menerbitkan saham baru (Irawan et al., 2016)

\section{Pengaruh Kepemilikan Manajerial Terhadap Kebijakan Hutang}

Kepemilikan manajerial sangat penting dalam mempengaruhi kebijakan hutang. Dalam struktur kepemilikan manajerial bahwa pemilik perusahaan dari pihak dalam (insider) mempunyai kekuataan yang besar untuk melakukan kebijakan hutang (Bhakti, 2012). Semakin meningkatnya kepemilikan insider, akan menyebabkan insider semakin berhati-hati dalam menggunakan hutang. Kepemilikan Manajerial yang semakin meningkat akan membuat management menjadi semakin hatihati dalam mengelola kebijakan hutang perusahaan, Berdasarkan penelitian terdahulu yang dilakukan (Ratnaningsih, 2016) menunjukan bahwa kepemilikan manajerial berpengaruh positif terhadap kebijakan hutang, Selain itu, menurut (Sheisarvian et al., 2015) dan (Rokhman, 2015) menunjukkan bahwa kepemilikan manajerial berpengaruh negatif terhadap kebijakan hutang. Dan sedangkan menurut hasil penelitian dari (Anggraini, 2015) menunjukan bahwa kepemilikan manajerial tidak berpengaruh terhadap kebijakan hutang H1: Kepemilikan manajerial berpengaruh terhadap kebijakan hutang

\section{Pengaruh Ukuran Perusahaan Terhadap Kebijakan Hutang}

Ukuran perusahaan besar memiliki keuntungan aktivitas serta lebih dikenal oleh publik dibandingakan dengan perusahaan kecil, Oleh karena itu, semakin besar ukuran perusahaan maka perusahaan semakin transparan dalam mengungkapkan kinerja perusahaan kepada pihak luar, dengan demikian perusahaan semakin mudah mendapatkan pinjaman (Rokhman, 2015).

Menurut (Dewi Permata Sari, 2018), (Irawan, et al, 2016), (Anggraini, 2015) dan (Rokhman, 2015) menunjukan bahwa ukuran perusahaan berpengaruh positif terhadap kebijakan hutang. Selain itu, menurut (Marhamah, 2016) menunjukan bahwa ukuran perusahan berpengaruh negatif terhadap kebijakan hutang, Dan sedangkan hasil penelitian yang dilakukan oleh (Husna dan Wahyudi, 2016) menunjukan bahwa ukuran perusahaan tidak berpengaruh terhadap kebijakan hutang. 
H2: Ukuran Perusahaan berpengaruh terhadap kebijakan hutang

\section{Pengaruh Kebijakan Dividen Terhadap Kebijakan Hutang}

Semakin besar dividen yang dibagikan kepada pemegang saham, maka kinerja emiten atau perusahaan akan semakin baik, dan perusahaan yang memiliki kinerja yang baik dianggap menguntungkan dan nilai perusahaan akan semakin baik, sehingga akan dimanfaatkan oleh kreditur untuk memberikan kepercayaan kepada perusahaan untuk memberikan kredit (Anggraini, 2015).

Penelitian terdahulu yang dilakukan oleh (Anggraini, 2015) menunjukan bahwa kebijakan dividen berpengaruh positif terhadap kebijakan hutang. Sedangkan hasil penelitian yang dilakukan (Sheisarvian et al., 2015) menunjukan bahwa kebijakan dividen berpengaruh negatif terhadap kebijakan hutang. Sedangkan hasil penelitian menurut (Anindhita et al, 2017) dan (Ratnaningsih, 2016) menunjukan bahwa tidak berpengaruh yang signifikan terhadap kebijakan hutang.

H3: Kebijakan Dividen berpengaruh terhadap kebijakan hutang

\section{METODE PENELITIAN Populasi dan Sampel}

Metode penelitian sampel yang digunakan adalah Purposive Sampling, yaitu tipe pemilihan sampel berdasarkan pertimbanganpertimbangan tertentu dan pertimbangan yang diambil itu berdasarkan tujuan penelitian. Sampel untuk penelitian ini adalah Perusahaan Manufaktur Sektor Industri Barang Konsumsi yang terdaftar di Bursa Efek Indonesia (BEI) selama tahun 2015-2019. Dari hasil pemilihan sampel dengan Purposive Sampling terpilih 9 perusahaan yang memenuhi kriteria. Metode Pengumpulan Data yang digunakan dalam penelitian ini adalah data sekunder yaitu data yang diperoleh peneliti secara tidak langsung melalui media perantara (diperoleh dan dicatat oleh pihak lain atau lewat dokumen). Data sekunder dalam penelitian ini berupa laporan tahunan perusahaan dan perusahaan manufaktur sektor industri barang konsumsi yang tercatat dalam Bursa Efek Indonesia (BEI) yang didapatkan melalui situs resminya di www.idx.co.id. Selain itu, data sekunder lain yang digunakan berupa jurnal yang berkaitan dengan penelitian.

\section{Metode Analisis Data}

Metode yang digunakan untuk mengetahui kepemilikan manajerial, ukuran perusahaan, dan kebijakan dividen terhadap kebijakan hutang digunakn analisis regresi data panel dengan program eviews 9. Model analisis regresi data panel:

$$
Y_{i t}=\beta_{0}+\beta_{1} \mathrm{X}_{\mathrm{it}}+\beta_{2} \mathrm{X}_{2 \mathrm{it}}+\beta_{3} \mathrm{X}_{3 \mathrm{it}}+{ }^{\varepsilon}{ }_{i t}
$$

Keterangan:

Y $\quad=$ Variabel Dependen

$\beta 0=$ Konstanta

$\beta 1,2,3=$ Koefesien Regresi Variabel Independen

$\mathrm{X} 1,2,3=$ Variabel Independen $\mathrm{i}=$ Perusahaan

$\mathrm{t} \quad=$ Waktu

$\varepsilon \quad=$ Residual / Error

\section{HASIL DAN PEMBAHASAN}

Pengujian terhadap hipotesis penelitian menggunakan analisis regresi data panel. Uji regresi data panel berfungsi untuk menjelaskan hubungan antara variabel bebas dan terikat yang di interprestasikan melalui suatu persamaan yang telah dibuat. Hasil perhitungan analisis regresi data panel dilakukan dengan program eviews 9,2020 . Seperti yang ditampilakan pada tabel 1 .

Tabel 1. Rangkuman Hasil Analisis Regresi Data Panel

\begin{tabular}{|l|c|c|c|}
\hline \multicolumn{1}{|c|}{ Hipotesis } & $\begin{array}{c}\text { Nilai (t- } \\
\text { statistik) }\end{array}$ & Sign. & Ket \\
\hline Constant & -2.246383 & 0.0301 & - \\
\hline $\begin{array}{l}\text { Kepemilikan } \\
\text { Manajerial } \\
\text { (H1) }\end{array}$ & 0.561387 & 0.5776 & Ditolak \\
\hline $\begin{array}{l}\text { Ukuran } \\
\text { Perusahaan } \\
(\mathrm{H} 2)\end{array}$ & 2.480751 & 0.0173 & Diterima \\
\hline
\end{tabular}




\begin{tabular}{|l|c|c|c|}
\hline $\begin{array}{l}\text { Kebijakan } \\
\text { Dividen (H3) }\end{array}$ & 1.609243 & 0.1152 & Ditolak \\
\hline $\begin{array}{l}\text { Adjusted } \mathrm{R}- \\
\text { squared }\end{array}$ & \multicolumn{3}{|c|}{0.143616} \\
\hline $\begin{array}{l}\text { Prob F } \\
\text { Statistik }\end{array}$ & \multicolumn{3}{|c|}{0.024853} \\
\hline
\end{tabular}

Sumber: Data diolah Eviews 9, 2020

\section{Pengaruh Kepemilikan Manajerial terhadap Kebijakan Hutang}

Dari hasil analisis diatas, maka diperoleh kesimpulan bahwa Kepemilikan Manajerial menghasilkan nilai t-statistik sebesar 0.561387 $<\mathrm{t}$ tabel sebesar 2,01954 dengan nilai Prob. Sebesar $0.5776>0,05$. Dari hasil uji t tersebut dapat disimpulkan bahwa Kepemilikan Manajerial yang diproksikan dengan Kepemilikan Manajerial (KM) tidak berpengaruh terhadap Kebijakan Hutang.

Dari hasil tersebut dapat dilihat bahwa, masih rendahnya kepemilikan saham oleh insider dibandingkan dengan kelompok lainnya dalam pembuatan keputusan pendanaan perusahaan. Jadi, untuk mengambil keputusan kebijakan pendanaan perusahaan tidak hanya dari external (hutang) saja, bisa dari dana internal yaitu laba di tahan. Oleh karena itu, kepemilikan manajerial tidak berpengaruh dalam mengambil keputusaan pendaan terhadap kebijakan hutang. Hasil penelitian ini sejalan dengan penelitian yang dilakukan oleh (Anggraini, 2015) yang menyatakan bahwa kepemilikan manajerial tidak berpengaruh terhadap kebijakan hutang. Dan tidak sejalan dengan penelitian yang dilakukan oleh (Ratnaningsih, 2016) menunjukan bahwa kepemilikan manajerial berpengaruh positif terhadap kebijakan hutang.

\section{Pengaruh Ukuran Perusahaan terhadap Kebijakan Hutang}

Dari hasil analisis diatas, maka diperoleh kesimpulan bahwa Ukuran Perusahaan menghasilkan nilai t- statistik sebesar 2.480751 $>\mathrm{t}$ tabel sebesar 2,01954 dengan nilai Prob. Sebesar $0.0173<0,05$. Dari hasil uji t tersebut dapat disimpulkan bahwa Ukuran Perusahaan yang diproksikan dengan SIZE berpengaruh signifikan terhadap Kebijakan Hutang. Semakin besar ukuran perusahaan maka perusahaan semakin transparan dalam mengungkapkan kinerja perusahaan kepada pihak luar, Karena ukuran perusahaan merupakan salah satu faktor yang dipertimbangkan perusahaan dalam menentukan berapa besar kebijakan keputusan pendanaan dalam memenuhi ukuran atau besarnya asset perusahaan.

Hasil penelitian ini sejalan dengan penelitian yang dilakukan oleh menurut (Dewi Permata Sari, 2018), (Irawan, et al, 2016), (Anggraini, 2015) dan (Rokhman, 2015) menunjukan bahwa ukuran perusashaan berpengaruh positif terhadap kebijakan hutang. Namun tidak sejalan dengan penelitian yang dilakukan oleh (Husna \& Wahyudi, 2016) menunjukan bahwa ukuran perusahaan tidak berpengaruh terhadap kebijakan hutang.

\section{Pengaruh Kebijakan Dividen terhadap Kebijakan Hutang}

Dari hasil analisis diatas, maka diperoleh kesimpulan bahwa Kebijakan Dividen menghasilkan nilai t-statistik sebesar 1.609243 $<\mathrm{t}$ tabel sebesar 2,01954 dengan nilai Prob. Sebesar $0.1152>0,05$. Dari hasil uji t tersebut dapat disimpulkan bahwa Kebijakan Dividen yang diproksikan dengan Dividen Payout Ratio (DPR) tidak berpengaruh signifikan terhadap Kebijakan Hutang.

Dengan demikian dapat disimpulkan bahwa semakin tinggi kebijakan dividen belum tentu perusahaan akan meningkatkan hutang. Perusahaan yang memiliki Dividen Payout Ratio yang tinggi menyukai pendanaan dengan modal sendiri dan disamping itu, pembayaran dividen dapat setelah kewajiban terhadap pembayaran bunga dan cicilan hutang perusahaan terpenuhi. Oleh karena itu, perusahaan memandang besar kecilnya dividen tidak mempengaruhi kebijakan perusahaan. Hasil penelitian ini sejalan dengan penelitian yang dilakukan oleh menurut (Anindhita et al, 
2017) dan (Ratnaningsih, 2016) menunjukan bahwa kebijakan dividen tidak berpengaruh yang signifikan terhadap kebijakan hutang. Namun tidak sejalan dengan penelitian yang dilakukan oleh (Anggraini, 2015) menunjukan bahwa kebijakan dividen berpengaruh positif terhadap kebijakan hutang.

\section{KESIMPULAN}

Berdasarkan hasil penilitian dan pembahasan pada bab sebelumnya, dapat diambil kesimpulan sebagai berikut: Pertama, Hasil analisis untuk variabel kepemilikan manajerial terhadap kebijakan hutang, diperoleh hasil yang menyatakan bahwa variabel kepemilikan manajerial tidak berpengaruh terhadap kebijakan hutang pada perusahaan manufaktur sektor industri barang konsumsi periode 2015-2019. Kedua, Hasil analisis untuk variabel ukuran perusahaan terhadap kebijakan hutang, diperoleh hasil yang menyatakan bahwa variabel ukuran perusahaan berpengaruh terhadap kebijakan hutang pada perusahaan manufaktur sektor industri barang konsumsi periode 2015-2019. ketiga,Hasil analisis untuk variabel kebijakan dividen terhadap kebijakan hutang, diperoleh hasil yang menyatakan bahwa variabel kebijakan dividen tidak berpengaruh terhadap kebijakan hutang pada perusahaan manufaktur sektor industri barang konsumsi periode 2015- 2019. Dan keempat, Kepemilikan Manajerial, Ukuran Perusahaan dan Kebijakan Dividen secara bersama-sama berpengaruh terhadap Kebijakan Hutang. Penelitian yang telah penulis lakukan ini memiliki banyak kekurangan dan keterbatasan. Nantinya keterbatasan yang dicoba penulis ungkapkan dapat menjadi referensi bagi penelitian sejenis dikemudian hari agar hasil penelitian selanjutnya dapat lebih baik dan sempurna.

\section{DAFTAR PUSTAKA}

Anggraini, N. (2015). Pengaruh Kepemilikan Manajerial, Kepemilikan Institusional, Kebijakan Dividen dan Ukuran Perusahaan Terhadap Kebijakan Utang ( Studi Pada Perusahaan Manufaktur di
Bursa Efek Indonesia ( BEI ). Jurnal Univesitas Pandanaran, 1(1).

Anindhita, N., et al . (2017). Pengaruh Kepemilikan Saham Institusi, Kepemilikan Saham Publik, Kebijakan Dividen, Struktur Aset, Dan Profitabilitas Terhadap Kebijakan Hutang Perusahaan Manufaktur Di Bursa Efek Indonesia Tahun 2012-2014. Jurnal Online Mahasiswa Fakultas Ekonomi Universitas Riau, 1(2), 1389-1403.

Bhakti, A. D. (2012). Pengaruh Struktur Kepemilikan Manajerial Dan Kepemilikan Institusional Terhadap Kebijakan Hutang Perusahaan Manufaktur Yang Terdaftar Di BEI Tahun 2009- 2011. Jurnal Ilmiah Mahasiswa FEB, 1(2), 1-20.

Brealey., et al. (2008). Dasar-dasar Manajemen Keuangan Perusahaan. Jakarta: Erlangga.

Dewi Permata Sari. (2018). Pengaruh Kepemilikan Institusional, Profitabilitas, Ukuran Perusahaan Terhadap Kebijakan Hutang. Jurnal Ilmu Akuntansi Mulawarman, 3(04), 116-138. https://doi.org/10.29040/jap.v15i 02.188

Dirvi Surya Abbas, Arry Eksandy. (2020). The Effect Of Effective Tax Rate, Tunneling Incentive, And Exchange Rate On Company Decisions To Transfer Pricing : Food And Consumption Sub-Sector Companies Listed On The Indonesia Evidence. Palarch's Journal Of Archaeology Of Egypt / Egyptology, 17(7), 14430-14442. Retrieved From Https://Archives.Palarch.N1/Index.Php/Jae /Article/View/5486

Eksandy, A. (2018). Metode Penelitian Akuntansi Dan Manajemen. Tangerang: FEB UMT.

Fried, I., dan Lang, H. . (1988). An Empirical Test of The Impact of Managerial Self-interest on Corporate Capital Structure. Journal of Finance, 43, 271-282.

Indahningrum, R. P., dan Handayani, R. (2009). Pengaruh Kepemilikan Manajerial, Kepemilikan Institusional, Dividen, Perumbuhan Perusahaan, Free Cash Flow dan Profitabilitas Terhadap Kebijakan Hutang Perusahaan. Jurnal Bisnis Dan Akuntansi, 11(3), 189-207.

Irawan, A., et al. (2016). Pengaruh Aset Berwujud, Ukuran Perusahaan, Pertumbuhan Perusahaan, Lama Perusahaan Dan 
Profitabilitas Terhadap Kebijakan Hutang

Pada Perusahaan Manufaktur Yang Terdaftar Di Bursa Efek Indonesia Periode Tahun 2010- 2014.Journal Of Accounting, 2(2). $\quad$ https://doi.org/10.1017/CBO978 1107415324.004

Jensen, M., dan Meckling, W. 1976. (1976). Theory of the Firm: Managerial Behavior Agency Cost and Ownership Structure. Journal of Finance Economics, 3,305-360. https://doi.org/10.1177/0018726 718812602

Kim, W. S., dan Sorensen, E. . (1986). Evidence on the Impact of the Agency Costs of Debt on Corporate Debt Policy. Journal of Financial and Quantitative Analysis, 21(2), 131-144.

Larasati, E. (2011). Pengaruh Kepemilikan Manajerial, Kepemilikan Institusional dan Kebijakan Dividen terhadap Kebijakan Hutang Perusahaan. Jurnal Ekonomi Bisnis, 16(2), 103-107.

Marhamah. (2016). Pengaruh Kepemilikan Manajerial, Kepemilikan Institusional, Kebijakan Deviden, Pertumbuhan (Growth), Ukuran Perusahaan, Dan Struktur Aktiva Terhadap Kebijakan Hutang Perusahaan Yang Terdaftar Di BEI. Jurnal STIE Semarang, 8(9), 16891699. https://doi.org/10.1017/CBO978 1107415324.004

Meythi. (2005). Konflik Keagenan: Tinjauan Teoritis Dan Cara Menguranginya. Jurnal Ilmiah Akuntansi, Vol. 5, pp. 7-17.

Novelma, S. (2014). Pengaruh Insider Ownership, Free Cash Flow dan Profitabilitas terhadap Kebijakan Dividen (Pada Perusahaan Manufaktur yang Terdaftar di Bursa Efek Indonesia). Jurnal Akuntansi, 2(1), 1-27.

Ratnaningsih, U. (2016). Pengaruh Kepemilikan Manajerial, Kepemilikan Institusional, Kebijakan Dividen, Struktur Aset dan Return On Asset (ROA) Terhadap Kebijakan Utang pada Perusahaan Manufaktur yang Terdaftar di Bursa Efek Indonesia Tahun 2010-2014. Jurnal Akuntansi Fakultas Ekonomi, 1-23.

Rokhman, M. T. N. (2015). Pengaruh Kepemilikan Manajerial, Kepemilikan Institusional, Ukuran Perusahaan, Pertumbuhan Perusahaan, Free Cash Flow Dan
Profitabilitas Terhadap Kebijakan Hutang Perusahaan Manufaktur Di Bursa Efek Indonesia. Ekonomi Bisnis, 1(2). https://doi.org/10.17977/um042v 21i2p122-135

Sheisarvian, R., et al. (2015). Pengaruh Kepemilikan Manajerial, Kebijakan Dividen Dan Profitabilitas Terhadap Kebijakan Hutang (Studi pada Perusahaan Manufaktur yang Tercatat di BEI Periode 2010- 2012). Jurnal Administrasi Bisnis S1 Universitas Brawijaya, 22(1), 85888.

Sugiyono. (2017). Metode Penelitian Kuantitatif, Kualitatif dan R\&D. Bandung.

Surya, D., dan Rahayuningsih, D. A. (2012). Faktorfaktor yang Mempengaruhi Kebijakan Hutang Perusahaan Non Keuangan yang Terdaftar Dalam Bursa Efek Indonesia. Jurnal Bisnis Dan Akuntansi, 14(3), 213225.

Susanto, Y. K. (2011). Kepemilikan Saham, Kebijakan Dividen, Karakteristik Perusahaan, Risiko Sistimatik, Set Peluang Investasi Dan Kebijakan Hutang. Jurnal Bisnis Dan Akuntansi, 13(3), 195-210. https://doi.org/10.34208/jba.v13i 3.236

Wahyudi, U., dan Pawestri, H. P. (2006). Implikasi Struktur Kepemilikan Terhadap Nilai Perusahaan: Dengan Keputusan Keuangan Sebagai Variabel Intervening. Simposium Nasional Akuntansi 9 Padang, 53, 160. https://doi.org/10.1017/CBO978 1107415324.004

Yeniatie, dan Destriana, N. (2010). Faktor - Faktor Yang Mempengaruhi Kebijakan Hutang Pada Perusahaan Non Keuangan Yang Terdaftar Di Bursa Efek Indonesia. Jurnal Bisnis Dan Akuntansi, 12(1), 16. https://doi.org/10.25105/jmat.v1i 1.4904

Zefriyenni, Sari, V. N., dan Utami, S. (2019). Korelasi Kebijakan Dividen, Ukuran Perusahaan dan Profitabilitas Terhadap Kebijakan Hutang pada Perusahaan Manufaktur. Jurnal Informatika Ekonomi Bisnis, 1(4), 28-33. https://doi.org/10.37034/infeb.v1 i4.7

https://economy.okezone.com/read/2 018/07/10/278/1920279/terlilit- utangsimak-karut-marut-keuangan- tiga-pilarsejahtera-food 


https://www.idx.co.id/
https://ekonomi.kompas.com/read/20
19/01/11/153635826/menguraiperma
salahan-dan-isu-pailit-yang-dialami-
produsen-taro?page=all
https://tirto.id/kenapa-perusahaan-
bisa-pailit-cUoh teh-sariwangi-
https://www.merdeka.com/peristiwa/ nyonya-
meneer-dari-konflik- keluargahingga-
utang-berujung- pailit.html

